\title{
A Study on the Reasons for the Inefficiency of College English Teaching and Some Tentative Countermeasures
}

\author{
Zhaogang Wang ${ }^{1}$ \\ ${ }^{1}$ School of International Business Communications, Dongbei University of Finance and Economics, Dalian, \\ China \\ Correspondence: Zhaogang Wang, School of International Business Communications, Dongbei University of \\ Finance and Economics, 116025 Dalian, China. Tel: 86-411-8474-3192. E-mail: frankwzg@163.com
}

Received: October 8, 2013 Accepted: November 3, 2013 Online Published: December 5, 2013

doi:10.5539/elt.v7n1p9 URL: http://dx.doi.org/10.5539/elt.v7n1p9

\begin{abstract}
On the basis of a survey, the reasons for the inefficiency of current College English teaching are examined. First, the traditional learning methodology is entrenched and the concepts and ideology of language teaching are outdated. Second, the social and learning environment resulted in the conflicts between the purpose of English teaching and the nature of language as a tool of communication. Third, textbooks and teaching materials cannot meet the requirements of social development and practical purposes. Four, the pedagogy of College English teaching is old-fashioned, and unable to create an appropriate environment for English learning. Five, students' learning methods are passive and mechanistic. As a result of the analysis, some tentative countermeasures are proposed to improve the efficiency of College English teaching. First, the ideology of English teaching should be shifted from being linguistic-knowledge-oriented to communication-oriented. Second, teaching materials should be changed from literary texts to more practical material. Third, the methods of College English teaching should be shifted from being teacher-centered to being student-centered. Four, more multimedia materials should be used in College English teaching. Five, the focus of College English teaching should be shifted from the practice of language skills to cross-cultural communications.
\end{abstract}

Keywords: reasons, inefficiency, College English teaching, countermeasures

\section{Introduction}

One of the important purposes of modern education is to prepare talents for economic development and social progress. With the increasing integration of Chinese economy with world economy, college graduates with good English skills are always at a premium on the job market. Consequently, College English as one of most widely offered courses is the center of attention for parents of college students, employers and government agencies. Although the last three decades have seen College English teaching (CET) developing very quickly, it is still far from meeting the requirements of economic and social development (Cen, 2009). The inefficiency of CET has been criticized by educators and employers for a long time and the problem must be tackled immediately (He, 2007). Therefore, with increasing economic globalization, how to improve the efficiency of CET, develops the potential of college students in CET, and enable college graduates to communicate in English in a cross-cultural context is an urgent issue.

\section{Methodology}

\subsection{The Purpose of the Study}

Although there are many studies on the effects of CET in recent years, surveys and empirical studies on this subject are seldom conducted. With a view to find out the effects of CET and the constraints on the efficiency of CET so as to propose corresponding solutions, we carried out a survey among some students in March, 2013.

\subsection{Respondents of the Survey}

293 students (76 males and 217 females) are surveyed, who were admitted to the college in September 2010, studying various subjects including international trade, international finance, statistics, public finance, economics, law, business administration, accounting and information management system. They have completed the two-year required courses of CET at the time of the survey. 


\subsection{Tool of the Study}

A questionnaire is used in the survey. 2 to 4 choices follow each question in the questionnaire. Students are asked to choose the most appropriate answer to each question according to their own scenarios in their College English learning process. The questions are mostly concerned with their evaluations on their two years of College English learning and their views and strategies of English learning.

\subsection{Data Collection and Analysis}

The study surveyed students from departments other than the English Department, and only one class from each department were chosen to participate in the study. The selection of different classes from each department was based on the schedule of students, and those who had classes in the afternoon of the survey week were asked to spend 20 to 30 minutes to answer the questions in the questionnaire. Because these students have completed two years of College English, they can fill in the questionnaire honestly without worrying about the results that may bring them trouble. After the survey, the results are analyzed statistically.

\section{Discussion of the Results}

\subsection{The Effects of CET}

\subsubsection{College English is the Most Time-Consuming and Exhausting of All the Courses}

In our survey, most respondents had 8 to 12 years of English learning before starting college. In the two years of College English courses, students have 5 hours of English lessons every week. Table 1 shows that most students have to spend 2 hours on English learning every day in addition to their formal classroom learning.

Table 1. The average amount of time spent on English learning every day in an average week (in addition to English classes)

\begin{tabular}{llll}
\hline Less than 1 hour & Approximately 2 hours & Approximately 3 hours & More than 4 hours \\
\hline $30 \%$ ( 87 students $)$ & $41 \%$ ( 120 students $)$ & $17 \%$ ( 51 students $)$ & $12 \%$ ( 35 students $)$ \\
\hline
\end{tabular}

\subsubsection{Students Are Dissatisfied with the Results of College English Teaching and Learning}

Table 2. The overall evaluation of College English teaching and learning by students after completing the required courses

\begin{tabular}{|c|c|c|c|c|}
\hline \multirow{2}{*}{$\begin{array}{l}\text { Students who think of } \\
\text { College English as a way of } \\
\text { getting diploma or who } \\
\text { think College English } \\
\text { should not be a required } \\
\text { course. }\end{array}$} & \multicolumn{2}{|c|}{$\begin{array}{l}\text { students who will continue their English } \\
\text { learning after two years of College } \\
\text { English courses }\end{array}$} & \multicolumn{2}{|c|}{$\begin{array}{l}\text { students who will not continue their } \\
\text { English learning after two years of } \\
\text { College English courses }\end{array}$} \\
\hline & \multicolumn{2}{|l|}{$74 \%$ ( 217 students) } & \multicolumn{2}{|l|}{$26 \%$ ( 76 students) } \\
\hline \multirow{2}{*}{$\begin{array}{l}\text { Students' overall evaluation } \\
\text { of CET }\end{array}$} & very satisfied & satisfied & not very satisfied & dissatisfied \\
\hline & $1 \%$ (4 students) & $11 \%(32$ students) & $52 \%(152$ students $)$ & $36 \%(105$ students $)$ \\
\hline \multirow{2}{*}{$\begin{array}{l}\text { Students' self-assessment of } \\
\text { the impacts of College } \\
\text { English on their overall } \\
\text { English competence }\end{array}$} & very effective & effective & not very effective & ineffective \\
\hline & $0 \%$ (1 students) & $9 \%$ (27 students) & $51 \%(148$ students $)$ & $40 \%$ (117 students) \\
\hline \multirow{2}{*}{$\begin{array}{l}\text { Students' expectations for } \\
\text { the quality of CET }\end{array}$} & very high & high & not very high & low \\
\hline & $1.3 \%$ (4 students) & $1.7 \%$ (5 students) & $15 \%$ (45 students) & $82 \%(239$ students $)$ \\
\hline \multirow{2}{*}{$\begin{array}{l}\text { The effects of College } \\
\text { English on students' } \\
\text { interest in learning English }\end{array}$} & very interested & interested & not interested & disgusted \\
\hline & $7 \%$ ( 21 students) & $43 \%$ (126 students) & $37 \%$ (109 students) & 13\% (37 students) \\
\hline
\end{tabular}

Table 2 shows that the majority of students $(88 \%)$ is not satisfied with the quality of CET. Half of the students lost interest in English learning after two years of College English courses. The survey reveals that most 
respondents said that College English failed to enhance their English competence significantly and it is far from living up to students' expectations.

\subsubsection{Students' Language Competence Can't Meet the Requirements of Social and Economic Development}

Table 3. Students' language proficiency after two years of College English learning

\begin{tabular}{|c|c|c|c|c|}
\hline \multirow[t]{2}{*}{ Listening } & $\begin{array}{l}\text { Able to understand } \\
\text { teachers' English }\end{array}$ & $\begin{array}{l}\text { Able to understand } \\
\text { simple English } \\
\text { conversations }\end{array}$ & $\begin{array}{l}\text { Unable to } \\
\text { understand teachers' } \\
\text { English }\end{array}$ & $\begin{array}{l}\text { Able to understand } \\
\text { English lectures }\end{array}$ \\
\hline & 67\% (195 students) & $8 \%$ (23 students) & $22 \%$ (65 students) & $3 \%$ (10 students) \\
\hline \multirow[t]{2}{*}{ Speaking } & $\begin{array}{l}\text { Able to express one's } \\
\text { ideas logically and } \\
\text { clearly }\end{array}$ & $\begin{array}{l}\text { Able to have simple } \\
\text { daily conversations }\end{array}$ & $\begin{array}{l}\text { Able to answer } \\
\text { questions in english } \\
\text { in the classroom }\end{array}$ & $\begin{array}{l}\text { Unable to speak } \\
\text { english }\end{array}$ \\
\hline & $0 \%$ (0 students) & $17 \%$ (51 students) & $53 \%$ (154 students) & $30 \%$ (88 students) \\
\hline \multirow[t]{2}{*}{$\begin{array}{l}\text { Everyday } \\
\text { conversations } \\
\text { foreigners }\end{array}$} & $\begin{array}{l}\text { Able to have such } \\
\text { conversations } \\
\text { smoothly }\end{array}$ & $\begin{array}{l}\text { Usually unable to } \\
\text { have } \\
\text { conversations }\end{array}$ & $\begin{array}{l}\text { Occasionally able to } \\
\text { have } \\
\text { conversations }\end{array}$ & $\begin{array}{l}\text { Unable to have } \\
\text { everyday } \\
\text { conversations with } \\
\text { foreigners }\end{array}$ \\
\hline & $0 \%$ (0 students $)$ & $7 \%$ (21 students) & $35 \%$ (102 students) & $58 \%$ (170 students) \\
\hline \multirow[t]{2}{*}{ Reading } & $\begin{array}{l}\text { Unable to understand } \\
\text { English reading } \\
\text { without teachers' } \\
\text { help }\end{array}$ & $\begin{array}{l}\text { Able to read } \\
\text { English newspapers } \\
\text { and magazines }\end{array}$ & $\begin{array}{l}\text { Able to read simple } \\
\text { English readings }\end{array}$ & $\begin{array}{l}\text { Able to read } \\
\text { English articles of } \\
\text { general topics }\end{array}$ \\
\hline & $14 \%$ (41 students) & $2 \%$ (5 students) & $59 \%$ (17 students) & $25 \%$ (73 students) \\
\hline \multirow[t]{2}{*}{ Writing } & $\begin{array}{l}\text { Able to write English } \\
\text { summaries of general } \\
\text { English articles }\end{array}$ & $\begin{array}{l}\text { Able to write } \\
\text { everyday practical } \\
\text { writings }\end{array}$ & $\begin{array}{l}\text { Able to write guided } \\
\text { compositions with } \\
\text { great efforts }\end{array}$ & $\begin{array}{l}\text { Unable to write } \\
\text { English essays } \\
\text { independently }\end{array}$ \\
\hline & $3 \%(9$ students $)$ & $7 \%$ (21 students) & $68 \%$ (199 students) & $22 \%$ (64 students) \\
\hline $\begin{array}{l}\text { Translation (the } \\
\text { ability to translate } \\
\text { passages easier than } \\
\text { articles in College } \\
\text { English textbooks) }\end{array}$ & $\begin{array}{l}\text { Able to translate the } \\
\text { entire passage } \\
2 \% \text { ( } 7 \text { students })\end{array}$ & $\begin{array}{l}\text { Able to translate } \\
\text { most of passages } \\
45 \% \text { (131 students })\end{array}$ & $\begin{array}{l}\text { Able to translate half } \\
\text { of the passage } \\
25 \% \text { (74 students) }\end{array}$ & $\begin{array}{l}\text { Unable to translate } \\
\text { independently } \\
28 \% \text { (81 students) }\end{array}$ \\
\hline
\end{tabular}

Language is a tool of communication. In order to be able to communicate in a foreign language, a language learner must reach certain levels of listening, speaking, reading, writing and translating skills, which are also the purpose of CET. However, Table 3 shows that after two years of College English learning, students' language competence is still far below the requirements of College English syllabus, and given the time and efforts that students have devoted to English learning, CET is very inefficient. It is very surprising that after two years of College English learning, 22\% of respondents said that they had great difficulties in understanding their teachers' lectures in English; 30\% said they could not speak any English at all; 58\% said that they could not have everyday conversations with foreigners at all. Although most students said they could finish guided writing tasks with great efforts, $22 \%$ have difficulties in finishing general writing tasks. Even with dictionaries, $28 \%$ are unable to translate English articles that are easier than textbook articles and they also could not translate Chinese material of familiar topics into English. The syllabus of College English requires that students should have fairly good reading skills, but only $25 \%$ are able to read intermediate articles of general topics and grasp their gist and relevant details. 


\subsubsection{Students Have Little Cultural Knowledge Related to Language Use}

Table 4. Students' knowledge about English culture after finishing College English learning

\begin{tabular}{|c|c|c|c|c|}
\hline $\begin{array}{l}\text { The contribution of CET } \\
\text { to students' understanding } \\
\text { of English culture }\end{array}$ & $\begin{array}{l}\text { Very much } \\
1 \%(2 \text { students })\end{array}$ & $\begin{array}{l}\text { Much } \\
18 \% \text { (54 students) }\end{array}$ & $\begin{array}{l}\text { Little } \\
55 \% \text { (160 students) }\end{array}$ & $\begin{array}{l}\text { Very little } \\
26 \% \text { ( } 77 \text { students) }\end{array}$ \\
\hline $\begin{array}{llr}\text { Aspects } & \text { of } & \text { students' } \\
\text { knowledge } & \text { about } & \text { English } \\
\text { culture } & & \end{array}$ & $\begin{array}{l}\text { Profiles of writers } \\
\text { and introductions of } \\
\text { famous writings }\end{array}$ & Values & $\begin{array}{l}\text { Customs and } \\
\text { traditions }\end{array}$ & $\begin{array}{l}\text { Patterns of } \\
\text { communication }\end{array}$ \\
\hline & $65 \%$ ( 191 students $)$ & $6 \%$ ( 17 students $)$ & $21 \%$ ( 61 students) & $8 \%$ ( 24 students) \\
\hline $\begin{array}{l}\text { Students' understanding of } \\
\text { conventions of English } \\
\text { conversations }\end{array}$ & $\begin{array}{l}\text { Very much } \\
1 \% \text { (3 students) }\end{array}$ & $\begin{array}{l}\text { Much } \\
12 \% \text { (36 students) }\end{array}$ & $\begin{array}{l}\text { Not much } \\
64 \% \text { (187 students) }\end{array}$ & $\begin{array}{l}\text { Little } \\
23 \% \text { (67 students) }\end{array}$ \\
\hline
\end{tabular}

Language learning and culture are inseparable. If language learners do not have a good understanding of the cultural background of the language, they will never be able to master that language (Du, 1999). It is evident that cross-cultural knowledge should be the core of foreign language teaching and it should be integrated into other parts of language teaching.

However, Table 4 shows that after two years of College English learning only 19\% of all respondents said that they had a good understanding of English culture while most students had little or very little knowledge about English culture. The cultural factors in College English classes are still limited to the introduction of writers and their writings included the English textbooks. Teachers give students very little introduction of values and patterns of communication which are the basis for appropriate use of the language. Students have little understanding of the conventions of English conversations and rules of communications in the target language. All this means that most College English teachers still focus their attention on the teaching of the target language and they view language as an abstract system of symbols in the cultural vacuum.

\subsection{Constraints on College English Teaching in China}

3.2.1 The Traditional Learning Methodology Is Entrenched and the Concepts and Ideology of Language Teaching Are Outdated

The ideology and concepts of language teaching predetermine the success of classroom activities because they have direct impact on the teaching process and the results of teaching. Chinese traditional ideology of native language learning has very strong impact on English language learning (Wen, 1996). When Chinese students are learning Chinese, they put more emphasis on acquiring knowledge by memorization, which developed a teaching ideology of emphasizing written language more than spoken language. As a result, Chinese English teachers pay more attention to the impartment of linguistic knowledge while students acquire the knowledge by memorization.

Table 5. Students' view on College English learning

\begin{tabular}{|c|c|c|c|}
\hline \multirow{2}{*}{$\begin{array}{l}\text { Linguistic accuracy is more } \\
\text { important than fluency. }\end{array}$} & Yes & Undecided & No \\
\hline & $50 \%$ (147 students) & $15 \%$ (44 students) & $35 \%$ (102 students) \\
\hline \multirow[t]{2}{*}{$\begin{array}{l}\text { The main activities in English } \\
\text { learning process }\end{array}$} & $\begin{array}{l}\text { Memorization of new } \\
\text { words and reading } \\
\text { the textbooks }\end{array}$ & $\begin{array}{l}\text { A large amount of } \\
\text { extracurricular readings }\end{array}$ & $\begin{array}{l}\text { Practice of speaking and } \\
\text { writing skills }\end{array}$ \\
\hline & $73 \%(214$ & $22 \%$ (65 students) & $5 \%$ (14 students) \\
\hline \multirow[t]{2}{*}{$\begin{array}{l}\text { The main responsibilities of } \\
\text { English teachers should be }\end{array}$} & $\begin{array}{l}\text { The impartment of } \\
\text { knowledge }\end{array}$ & $\begin{array}{l}\text { Coordinating cla } \\
\text { discussions }\end{array}$ & $\begin{array}{l}\text { Offering help to students who } \\
\text { learn by themselves and } \\
\text { answering students' questions }\end{array}$ \\
\hline & $43 \%$ (126 students) & $38 \%$ (112 students) & $19 \%$ (55 students) \\
\hline $\begin{array}{l}\text { Teachers' preference for } \\
\text { teaching material and activities }\end{array}$ & $\begin{array}{l}\text { The impartment of } \\
\text { linguistic knowledge }\end{array}$ & $\begin{array}{l}\text { The practice of language } \\
\text { skills }\end{array}$ & $\begin{array}{l}\text { Linguistic knowledge and the } \\
\text { practice of language skills }\end{array}$ \\
\hline
\end{tabular}




\begin{tabular}{llll}
\hline & $53 \%$ (154 students) & \multicolumn{1}{c}{$15 \%$ (44 students) } & \multicolumn{1}{c}{$32 \%$ (95 students) } \\
\hline Students preference & for & The accumulation of linguistic knowledge & The practice of language skills \\
English learning activities & $63 \%$ (184 students) & $37 \%$ (109 students) \\
\hline
\end{tabular}

Table 5 reflects learners' and teachers' beliefs in CET. We can see very clearly the impacts of traditional ideology of language teaching on English teaching: teachers believe their top priority is to impart knowledge and students think their job in learning English is to acquire linguistic knowledge. To some extent, both of them think the accumulation of linguistic knowledge is equivalent to the improvement of language skills, which is against the law of language teaching and ignores the cultivation of practical language competence. The survey shows $65 \%$ think that the adequate accumulation of linguistic knowledge is a prerequisite for the development of language skills. For a long time, English teachers in China have prioritized the acquisition and accumulation of linguistic knowledge but ignored and trivialized the practice of language skills, which is why most of English learners in China are very incompetent in English speaking and listening skills after many years of hard work.

3.2.2 The Social and Learning Environment Resulted in the Conflicts between the Purpose of English Teaching and the Nature of Language as a Tool of Communication

One of the key functions of language is communication. If language learners have devoted a large amount of time and efforts to language learning but they could not put the new language to a good use, then foreign language teaching will lose its value. Therefore language teachers must teach their students the language as a tool of communication because only in real communicative activities can language learners understand the purpose of language learning and learn how to communicate in the new language (Shu \& Zhuang, 1996).

However, the social and learning environment resulted in the conflicts between the purpose of English teaching and the nature of language as a tool of communication. Table 6 shows the environmental factors that have impacts on CET includes evaluation standards of language teaching, social requirements, and teaching process. College English Test Band 4 (CET-4) and College English Test Band 6 (CET-6), which are mainly tests on students' acquisition of linguistic knowledge, are used to evaluate students' English proficiency. Employers use CET-4 and CET-6 as criteria for employability of graduates. As a result, CET has become test preparations for CET-4 and CET-6. All these show that CET overemphasizes the quantifiable elements in language learning while overlooking the unquantifiable measurements for communicative appropriateness and effectiveness (Lu, 1999).

Table 6. The orientation of College English teaching

\begin{tabular}{|c|c|c|c|c|c|c|}
\hline $\begin{array}{l}\text { The social attitudes and } \\
\text { the attitudes of college } \\
\text { authorities towards } \\
\text { CET- } 4 \text { and CET- } 6\end{array}$ & $\begin{array}{l}\text { CET- } 4 \text { and CET- } 6 \text { are } \\
\text { important } \\
64 \% \text { (186 students })\end{array}$ & very & $\begin{array}{l}\text { CET-4 and } \\
\text { important } \\
24 \% \text { ( } 71 \text { stude }\end{array}$ & CET-6 are & \multicolumn{2}{|c|}{$\begin{array}{l}\text { CET- } 4 \text { and CET- } 6 \text { are neither } \\
\text { important nor unimportant } \\
12 \% \text { ( } 36 \text { students })\end{array}$} \\
\hline \multirow[t]{2}{*}{$\begin{array}{l}\text { Students' aims } \\
\text { English learning }\end{array}$} & Tes & \multicolumn{2}{|c|}{$\begin{array}{l}\text { Career } \\
\text { requirements }\end{array}$} & \multicolumn{2}{|c|}{$\begin{array}{l}\text { Cross-cultural } \\
\text { communication }\end{array}$} & Ot \\
\hline & $25 \%$ & \multicolumn{2}{|c|}{$59 \%$ (173 students) } & \multicolumn{2}{|c|}{$9 \%$ (25 students) } & $7 \%$ \\
\hline \multirow[t]{2}{*}{$\begin{array}{l}\text { Main activities } \\
\text { English learning }\end{array}$} & $\begin{array}{l}\text { Memorization of new } \\
\text { words and texts }\end{array}$ & \multicolumn{2}{|c|}{$\begin{array}{l}\text { Test preparation for } \\
\text { CET-4 and CET-6 }\end{array}$} & \multicolumn{2}{|c|}{ Extensive reading } & $\begin{array}{l}\text { Practical use of } \\
\text { English }\end{array}$ \\
\hline & $29 \%$ & \multicolumn{2}{|c|}{ 41\% (119 students) } & \multicolumn{2}{|c|}{ 24\% (71 students) } & $6 \%$ (19 students) \\
\hline \multirow{2}{*}{$\begin{array}{l}\text { The main orientations } \\
\text { of College English } \\
\text { teaching }\end{array}$} & & \multicolumn{2}{|c|}{$\begin{array}{l}\text { Development of } \\
\text { learning methods }\end{array}$} & \multicolumn{2}{|c|}{$\begin{array}{l}\text { Test preparation and } \\
\text { knowledge impartment }\end{array}$} & Others \\
\hline & $16 \%$ (48 students) & \multicolumn{2}{|c|}{$14 \%$ (41 students) } & \multicolumn{2}{|c|}{$59 \%$ (173 students) } & $11 \%$ (31 students) \\
\hline
\end{tabular}

Ellis (1999) thinks social environment for language learning does not only determine learners' motivations but also determine which motivation is the most important for them in the learning process, because language learners' choices are subject to their social environment and individual learners' choices are based on their benefits and costs of language learning. Test-oriented learning has turned College English Teaching into a tool for obtaining CET-4 and CET-6 certificates. Such motivations of English learning prioritize the acquisition of linguistic knowledge in order to obtain good test results while overlooking the development of communicative competence. As a consequence, it is uncommon for many college students to have very high test scores but very 
poor communicative skills.

3.2.3 Textbooks and Teaching Material Cannot Meet the Requirements of Social Development and Practical Purposes

Textbooks are the vehicle of knowledge and teaching methodology and they are the most important teaching material. The purpose of foreign language teaching is not merely to develop students' language skills but to develop students' communicative competence, i.e. the ability to obtain and communicate new information with the foreign language so as to accomplish cross-cultural communication and contribute to economic construction and social development. With the challenges of the information age, knowledge economy and globalization, English textbooks and teaching material should follow the new trends to satisfy the multipurpose of CET for knowledge acquisition, language acquisition and communication. CET should not only improve students' English proficiency, but also enable students to acquire new knowledge and improve their communicative skills in the learning process.

Table 7. Students' feedback on textbooks and teaching material

\begin{tabular}{|c|c|c|c|c|c|}
\hline $\begin{array}{l}\text { What do you think of } \\
\text { your textbooks and } \\
\text { teaching material? }\end{array}$ & $\begin{array}{l}\text { Very practical } \\
4 \% \text { (12 students })\end{array}$ & $\begin{array}{l}\text { Not very } \\
58 \%(17\end{array}$ & $\begin{array}{l}\text { ractical } \\
\text { students) }\end{array}$ & $\begin{array}{l}\text { Very } \\
38 \%\end{array}$ & $\begin{array}{l}\text { npractical } \\
110 \text { students) }\end{array}$ \\
\hline $\begin{array}{l}\text { Are teaching materials } \\
\text { conducive to your } \\
\text { development of } \\
\text { communicative skills? }\end{array}$ & $\begin{array}{l}\text { Very useful } \\
1 \% \text { (4 students) }\end{array}$ & $\begin{array}{l}\text { Useful } \\
24 \% \text { ( } 70 \text { students) }\end{array}$ & $\begin{array}{l}\text { Not very } \\
49 \%(14\end{array}$ & dents) & $\begin{array}{l}\text { Useless } \\
26 \% \text { (75 students) }\end{array}$ \\
\hline $\begin{array}{l}\text { Are textbooks and } \\
\text { teaching material useful } \\
\text { for arousing your } \\
\text { interests in English } \\
\text { communication? }\end{array}$ & $\begin{array}{l}\text { Very useful } \\
2 \% \text { (7 students) }\end{array}$ & $\begin{array}{l}\text { Useful } \\
21 \% \text { (60 students) }\end{array}$ & $\begin{array}{l}\text { Not very } \\
43 \%(12\end{array}$ & dents) & $\begin{array}{l}\text { Useless } \\
34 \% \text { (100 students) }\end{array}$ \\
\hline $\begin{array}{l}\text { Can what you learn } \\
\text { reflect the trend of } \\
\text { social development? }\end{array}$ & $\begin{array}{l}\text { Yes } \\
2 \%(5 \text { students })\end{array}$ & $\begin{array}{l}\text { Roughly yes } \\
16 \% \text { (47 students) }\end{array}$ & $\begin{array}{l}\text { Roughly } \\
47 \%(13\end{array}$ & dents) & $\begin{array}{l}\text { No } \\
35 \% \text { (103 students })\end{array}$ \\
\hline
\end{tabular}

Table 7 shows that most English learners are not satisfied with their textbooks and teaching material because they think that their textbooks are outdated, out of touch with reality, impractical and unable to facilitate the improvement of their communicative competence. One of the main reasons resulting in the stark contrast between students' high test scores and their low communicative competence is probably the selection of some classical literature as English teaching material and the traditional ideology of Chinese learning.

3.2.4 The Pedagogy of CET Is Old-Fashioned, and Unable to Create an Appropriate Environment for English Learning

The main parts of the language teaching process are carried out in the classroom. Classroom activities will embody the methodology of the syllabus. The classroom is also the main place for students and teachers to communicate with each other and it is also the place where teachers exert their influence on students' motivations, coordinate students' activities and ensure the quality of language input (Shu and Zhuang, 1996). Therefore, the methodology of classroom teaching will definitely has a direct impact on students' learning behavior and the results of teaching.

Table 8. Patterns and Methods of CET

\begin{tabular}{|c|c|c|c|}
\hline $\begin{array}{l}\text { Which of the three } \\
\text { scenarios best describe } \\
\text { the methods of CET in } \\
\text { the classroom? }\end{array}$ & $\begin{array}{l}\text { Teachers do all the talking } \\
\text { by explaining the language } \\
\text { points in the text. } \\
51 \% \text { ( } 149 \text { students) }\end{array}$ & $\begin{array}{l}\text { Teachers do most of the } \\
\text { talking. }\end{array}$ & $\begin{array}{l}\text { Student-centered } \\
\text { communicative activities } \\
\text { dominate the classroom } \\
9 \% \text { ( } 26 \text { students })\end{array}$ \\
\hline $\begin{array}{l}\text { nich of the three } \\
\text { enarios best describe } \\
\text { patterns of CET? }\end{array}$ & $\begin{array}{l}\text { Teacher-centered } \\
59 \% \text { (173 students) }\end{array}$ & $\begin{array}{l}\text { Guided } \\
23 \%(67\end{array}$ & $\begin{array}{l}\text { Heuristic } \\
9 \% \text { (26 students) }\end{array}$ \\
\hline
\end{tabular}




\begin{tabular}{|c|c|c|c|c|}
\hline \multirow[t]{2}{*}{$\begin{array}{l}\text { What do you think of } \\
\text { the methods of CET? }\end{array}$} & Flexible and varied & Fairly varied & $\begin{array}{l}\text { Relatively } \\
\text { monotonous }\end{array}$ & Fixed \\
\hline & $4 \%$ (13 students) & $7 \%$ (21 students) & $51 \%$ (148 students) & $38 \%$ (111 students) \\
\hline \multirow{2}{*}{$\begin{array}{l}\text { What are the main } \\
\text { technologies used in the } \\
\text { College English class? }\end{array}$} & $\begin{array}{l}\text { Chalk } \\
\text { chalkboard }\end{array}$ & Multimedia & Internet & Others \\
\hline & $20 \%$ (59 students) & $75 \%$ (220 students) & $3 \%$ (8 students) & $2 \%$ (5 students) \\
\hline $\begin{array}{l}\text { How do you describe } \\
\text { the atmosphere in the } \\
\text { classroom? }\end{array}$ & $\begin{array}{l}\text { Very active } \\
1 \%(2 \text { students })\end{array}$ & $\begin{array}{l}\text { Active } \\
9 \% \text { (26 students) }\end{array}$ & $\begin{array}{l}\text { Relatively boring } \\
55 \% \text { (162 students) }\end{array}$ & $\begin{array}{l}\text { Monotonous } \\
35 \% \text { (103 students) }\end{array}$ \\
\hline
\end{tabular}

Foreign language learning entails a large amount of practice for learners. The social and communicative nature of language distinguishes language learning from the study of other subjects. Language learning involves communication with others. Therefore it does not only require certain cognitive competence but also requires necessary social and communicative skills (Williams \& Burden, 2000). In other words, although knowledge impartment is an indispensable part of language learning, an atmosphere of active participation and genuine communication is more important. Therefore, foreign language learning should be student-centered but not teacher-centered.

However, Table 8 shows that College English teachers do almost all the talking in the classroom; their fixed, monotonous teaching methods cannot create a necessary atmosphere of genuine communication which foreign language learning requires; their inadequate use of modern technology cannot create the necessary environment for real communication to happen. These problems in CET have resulted in English learners' high test scores and low social and communicative skills.

\subsubsection{Students' Learning Methods Are Passive and Mechanistic}

Learners are the key element in the learning process and their motivations are the internal driving force in the learning and teaching process, therefore the success of learning depends on them. The syllabus of CET states that students should become real active learners.

Table 9. Survey of students' English learning strategies

\begin{tabular}{|c|c|c|c|c|}
\hline \multirow[t]{2}{*}{$\begin{array}{l}\text { The key to successful } \\
\text { English learning }\end{array}$} & Students' hard work & Talent & Teachers' help & $\begin{array}{l}\text { Learning } \\
\text { environment }\end{array}$ \\
\hline & $52 \%$ (152 students) & $7 \%$ (21 students) & $8 \%$ (24 students) & $33 \%$ (96 students) \\
\hline \multirow{2}{*}{$\begin{array}{l}\text { The planning of } \\
\text { College } \\
\text { learning }\end{array}$} & \multicolumn{4}{|c|}{$\begin{array}{l}\text { I follow teachers' arrangement and I I have my own learning plan } \\
\text { don't have clear schedule of my own }\end{array}$} \\
\hline & \multicolumn{3}{|l|}{$53 \%$ (156 students) } & \\
\hline \multirow{2}{*}{$\begin{array}{l}\text { Reflection and } \\
\text { evaluation on one's } \\
\text { learning strategies }\end{array}$} & Often & Sometimes & Occasionally & Seldom \\
\hline & $25 \%$ (74 students) & $42 \%$ (124 students) & $22 \%$ (64 students) & $11 \%$ (33 students) \\
\hline \multirow{2}{*}{$\begin{array}{l}\text { Opinions on classroom } \\
\text { discussions and } \\
\text { participations }\end{array}$} & Effective & A waste of time & $\begin{array}{l}\text { Teachers' explanations } \\
\text { are better }\end{array}$ & Boring \\
\hline & $43 \%$ (126 students) & $18 \%$ (53 students) & $34 \%$ (100 students) & $5 \%$ (14 students $)$ \\
\hline \multirow{2}{*}{$\begin{array}{l}\text { Extracurricular } \\
\text { activities of language } \\
\text { learning }\end{array}$} & Often & Sometimes & Seldom & Never \\
\hline & $2 \%$ (7 students) & $38 \%$ (111 students) & $47 \%$ (138 students) & $13 \%$ (37 students) \\
\hline \multirow[t]{2}{*}{ Status in English class } & \multicolumn{4}{|c|}{$\begin{array}{llll}\begin{array}{l}\text { Passive listening teachers' } \\
\text { explanations }\end{array} & \begin{array}{l}\text { Active participation of Occasional participation } \\
\text { classroom activities }\end{array}\end{array}$} \\
\hline & $55 \%$ (160 students) & $12 \%$ (35 studen & $33 \%$ (98 st & idents) \\
\hline \multirow[t]{2}{*}{$\begin{array}{l}\text { The main hindrance to } \\
\text { classroom participation }\end{array}$} & $\begin{array}{l}\text { Passive habits formed } \\
\text { in traditional learning } \\
\text { environment }\end{array}$ & $\begin{array}{l}\text { Lack } \\
\text { opportunities }\end{array}$ & $\begin{array}{l}\text { Afraid of making } \\
\text { mistakes and being } \\
\text { scoffed }\end{array}$ & Lack of interest \\
\hline & $64 \%$ (187 students) & $9 \%(27$ students $)$ & $11 \%$ (31 students) & $16 \%$ (48 students) \\
\hline
\end{tabular}




\begin{tabular}{lllll}
\hline Self-learning & Often & Sometimes & Occasional & Seldom \\
& $36 \%(105$ students $)$ & $37 \%(108$ students $)$ & $19 \%(56$ students $)$ & $8 \%(24$ students $)$ \\
\hline
\end{tabular}

Table 9 shows that English learners' efforts determine their success to a large extent. Since more than half of all English learners admit that their own efforts are the critical factor in their learning, are learners' inadequate efforts the main reasons for the inefficiency of College English teaching and learning or are there other reasons? According to the survey, individual interviews, and long-time observations, we think that the main reasons for that are the passive learning strategies of students. First, students have very poor self-autonomy in English learning. For example, $64 \%$ of all respondents said that they could not persist in learning English by themselves. $57 \%$ do not like communicative activities such as classroom discussions. At least $55 \%$ have formed habits of passive reception of teachers' explanations. 98\% seldom participate in extracurricular English learning activities. Second, students do not have careful planning for English learning. 53\% do not have their own learning plans and they just followed their teachers' schedules and requirements. Third, students overlook the monitoring of their learning process. Most students (75\%) seldom reflect and evaluate the effects of their learning strategies. Therefore, the prevalent passive attitude towards English learning is one of the main reasons for the low efficiency of College English teaching and learning.

\section{Suggestions to Improve the Effects of CET}

Foreign language teaching and learning is a complicated and systematic process. If students want to be able to use English as a tool of cross-cultural communication, and if teachers want to improve the unfavorable inefficiency of CET, the following changes should be made:

\subsection{The Ideology of English Teaching Should Be Shifted from Being Linguistic Knowledge-Oriented to Communication-Oriented}

Language is the product of social communication and interaction, which give language life. People can only learn how to use a language in genuine communications (Shu \& Zhuang, 1996). In other words, practical language use is the purpose of language learning and it also guarantees the success of language learning. Linguistic knowledge is the foundation of practical language use, but knowledge is not equivalent to competence and having adequate linguistic knowledge does not guarantee high levels of practical language use. Learners will not be able to understand and use a language just because they have memorized a thousand grammatical rules, a thousand verb forms and three thousand words. Clearly, CET should not be limited to the impartment and study of linguistic knowledge because the separation of linguistic knowledge from practical language use will not enable students to acquire the language competence they need to accomplish successful cross-cultural communications.

Therefore, to improve the efficiency and effects of College English teaching, teachers should balance between linguistic usage and language use and they must realize profoundly that linguistic usage as an indispensable part of practical language use is not able to guarantee learners' successful language use while practical language use is able to promote the mastery of linguistic usage (Widdowson, 1999). In English learning and teaching process, the relationship between cognition and practice should be handled seriously (Xia, 1997). Language teaching and learning should be shifted from learning how to communicate to learning in communication (Xia, 2000). Naturally, the serial changes in language pedagogy hinge on favorable environment of language evaluation and scientific methods of language assessment. For the time being, CET should not focus on test preparation and testing methods should be reformed in order to realize the change in College English teaching from result-oriented to process-oriented.

\subsection{Teaching Material Should Be Changed from Literary Texts to More Practical Material}

The purpose of foreign language teaching and learning is not to cultivate writers but to educate talents for economic construction and social development. Given the fact that economic globalization and the production and distribution of knowledge and information characterize the 21st century, foreign language education should focus on students' comprehensive competence and creativity in order to adapt itself to the requirements of the information age and to the social needs of cross-cultural communication. In terms of the relationship between language learning and social development, language learning is the product of social development and it will grow along with social, economic, cultural, and scientific development. As a result, the contents of foreign language teaching should reflect the reality of social development. Constructivists think that learning includes meaningful and meaningless learning and only when learners think that what they are learning is relevant to them can they participate in the learning process actively which will result in meaningful learning (Williams \& 
Burden, 2000). Widdowson (1999) points out that foreign language learning should be combined with the learning of other subjects which will not only guarantee the connection between the contents of foreign language teaching and students' personal experience but also provide approaches to genuine communications which in turn encourage students not only to learn the usage of the foreign language but also to use the foreign language.

Therefore, in view of the instrumentality of language and the improvement of students' comprehensive competence and long-term development, the contents of CET should not only be limited to literary works but also include material that is up-to-date, practical, and cross-cultural so as to realize the shift from linguistic skill-based teaching to content-based teaching which enables students to acquire valuable knowledge while learning linguistic skills.

\subsection{The Methods of CET Should Be Shifted from Being Teacher-Centered to Being Student-Centered}

Students cannot master English by listening to their teachers' explanations of the language. Students need a large amount of practice before they can grasp a language. Therefore, the main tasks of English teaching are to cultivate students' ability to learn by themselves and their abilities to employ the language whenever possible. The impartment of linguistic knowledge will be meaningful when it helps to guide the practice of language skills.

Social constructivists think that the acquisition of knowledge is in nature the process of reconstruction by learners themselves which is the result of social interactions (Williams \& Burden, 2000). In terms of the laws of language learning, although the acquisition of linguistic knowledge contributes to the growth of linguistic competence, linguistic knowledge will be transformed into communicative competence through enormous practice. That means English teaching should be learner-centered and classrooms should become the places for communicative activities. English teachers should change themselves from being the knowledge-givers and the dominant figures to the playwrights, directors and consultants in the classroom. The relationship between teachers and students is more like coaches and athletes rather than actors and audience. Classroom activities should be changed from unilateral activities to bilateral and multilateral activities. Teachers should motivate their students through equal participation and student-centered activities.

In addition, because foreign language learning is a life-long process, College English teachers should also help their students to develop good learning strategies so that they can employ these good strategies to learn by themselves after college. English learning strategies are even more useful than specific linguistic knowledge or exercises for language skills because students with good learning strategies will be more creative and successful in their learning process (Du, 1999).

\subsection{More Multimedia Material Should Be Used in College English Teaching}

Foreign language is different from native language learning in that it lacks the necessary language environment. Without the particular language environment, a language becomes a system of abstract symbols. One of the key problems in traditional foreign language teaching is that language is taught as a system of abstract symbols. As a result, language learners are not only uninterested but also unable to use the language properly and appropriately.

Communication is a complicated encoding and decoding process, which involves many factors including non-verbal behavior and context apart from verbal behavior. One of the reasons for the inefficiency of College English teaching is that the traditional chalk-and-talk teaching method cannot create near-native language learning environment. Cognitive psychologists think multisensory learning is more comprehensive, profound and long-lasting (He \& Zhou, 1996). To some extent, English teaching is a creation of environment(scenario), the most important of which is to create an exciting, stimulating and active environment to keep both teachers and students passionate and activated (Wang, 1996). Therefore, in order to enhance the effects of College English teaching and motivate students to acquire the language through immersion, more multimedia material should be applied to create real, interesting, informative and communicative language environment.

\subsection{The Focus of College English Teaching Should Be Shifted from the Practice of Language Skills to Cross-Cultural Communications}

The purpose of language learning is to use it in communications, which is a social behavior subjected to cultural background. Kramsch (1999) stated that culture is not the fifth skill attached to the four language skills of listening, speaking, reading and writing. Culture is always the background of language learning and if the best language learners overlook cultural elements they will suffer because their communicative competence will be limited and their understanding of the world around them will be challenged. In addition, communication is not only the transmission of information but also the building and maintenance of relationship (Byram, 1997). That means the development of foreign language competence should focus on cross-cultural communicative 
competence but not ambiguous communicative skills.

In today's world, economic globalization and cross-cultural communication are prevalent. In the future, cross-cultural communications will be an indispensable part of our life and people without knowledge of multicultural background and cross-cultural competence will not be able to function properly (Du, 1999). Therefore, CET should prioritize the development of students' cross-cultural competence while developing their language competence. Only the integration of language, culture and communication will complete the process of College English teaching.

\section{References}

Byram, M. (1997). Teaching and Assessing Intercultural Communication Competence. Clevedon: Multilingual Matters Ltd.

Cen, J. (2009). The Current Situations of Foreign Language Teaching in China. Foreign Languages Teaching and Research, 32(1), 3-6.

Du, R. (1999). Cultural Awareness and Innovation. Beijing: Foreign Languages Teaching and Research Press.

Ellis, R. (1999). The Study of Second Language Acquisition. Shanghai: Shanghai Foreign Languages Education Press.

He, G., \& Zhou, J. (1996). The listening and speaking classes of English majors in Chinese Normal Universities. Computer-assisted Foreign Language Education, 17(4), 7-8.

He, Z. (2007). Pragmatics and English Learning. Shanghai: Shanghai Foreign Languages Education Press.

Kramsch, C. (1999). Context and Culture in Language Teaching. Shanghai: Shanghai Foreign Languages Education Press.

Lu, G. (1999). Some Reflections on English Teaching. Beijing: Foreign Languages Teaching and Research Press.

Wang, X. (1996). On the application of Multimedia to the teaching of English texts. Computer-assisted Foreign Language Education, 17(4), 34-35.

Wen, Q. (1996). On English Learning Strategies. Shanghai: Shanghai Foreign Languages Education Press.

Widdowson, H. G. (1999). Teaching Language as Communication. Shanghai: Shanghai Foreign Languages Education Press.

Williams, M., \& Burden, R. L. (2000). Psychology for Language Teachers. Beijing: Foreign Languages Teaching and Research Press.

Shu, D., \& Zhuang, Z. (1996). Modern Theories, Practice and Methods of Foreign Language Teaching. Shanghai: Shanghai Foreign Languages Education Press.

Xia, J. (1997). Reflections on the design of College English textbooks in the 21st century. Beijing: Tsinghua University Press.

Xia, J. (2000). A study on the factors that influence College English teaching. Foreign Language World, 22(4), $2-6$.

\section{Copyrights}

Copyright for this article is retained by the author(s), with first publication rights granted to the journal.

This is an open-access article distributed under the terms and conditions of the Creative Commons Attribution license (http://creativecommons.org/licenses/by/3.0/). 